\title{
Electrochemical Biosensor for the Immediate Detection of Bacteria
}

\section{Amlil $A^{1}$, Koffi OEAB ${ }^{1,2}$, Bile BEA ${ }^{2}$, Bengourram $\mathrm{J}^{3}$, Najih $\mathrm{R}^{1}$, Latrache $\mathrm{H}^{4}$ and Chtaini $\mathrm{A}^{1 *}$}

${ }^{1}$ Faculty of Science and Technology, University Sultan Moulay Slimane, Morocco

${ }^{2}$ Laboratory Physical Chemistry, University of Cocody Felix Houphouet Boigny, Côte d'Ivoire

${ }^{3}$ Laboratory Industrial Engineering, Faculty of Science and Technology of Beni Mellal, Morocco

${ }^{4}$ Laboratory of Bioprocess and Biointerfaces, Faculty of Science and Technology of Beni Mellal, Morocco

\begin{abstract}
In this paper, a novel antibiotic modified carbon paste electrode (AMX-CPE) was fabricated for the directly determination of bacteria, such Staphylococcus aureus in physiological media. Electrochemical properties and morphological study of the modified electrode were greatly studied. We report a sensitive electrochemical voltammetric method for the immediate bacteria analyzing. A Staphylococcus bacterium adsorbed on an AMX-CPE surface and provides facile electrochemical quantitative methods for electroactive bacteria. Operational parameters have been optimized, and the stripping voltammetric performance has been studied using cyclic voltammetry (CV). The peaks current intensity is highly linear, with a good sensitivity of AMX-CPE.
\end{abstract}

Keywords: Modified Electrodes; SWV; CV; Bacteria; Biosensor

\section{Introduction}

Among the pathogens disseminated in water sources, enteric pathogens are the ones most frequently encountered. As a consequence, sources of fecal pollution in waters devoted to human activity must be strictly controlled. The detection and determination immediate of bacteria are essential for accurate diagnosis of the disease and effective treatment of the infection. Several methods of identifying bacteria are available. Traditional methods are based on phenotypic identification of the pathogen using the Gram staining, culture and biochimiques methods. However, these methods have some disadvantages such as their limited use of the microorganisms grown in vitro, or the diversity of strains that do not necessarily have the same biochemical characteristics, which makes complicated the analysis [1-4].

Recently, molecular analysis techniques have shown high efficiency in the detection of microorganisms, and the problems related to the phenotypic limitation are overcome. Among these tests, nucleic acid based detection is commonly applied for detection. Polymerase chain reaction (PCR) is highly sensitive and allows quantitation of bacteria at a species level $[5,6]$. In fact, real time PCR has become an indispensable tool in molecular diagnostic, forensic analysis, tumor diagnostic and determination of specific bacteria in samples. Serious research has focused on electrochemical methods of analysis, which offer high sensitivity along with cost and time effectiveness [7,8].

Electrochemical biosensors have several advantages, compared with other biosensors, such as:

- They are highly accurate, reproducible and exhibit a high linearity over a wide range of concentrations, they require no pretreatment of the analyte;

- $\quad$ They can offer advantages of low detection limits, and good stability.

The aim of the work reported here was to investigate the electrochemical properties of Staphylococcus aureus on Amoxil modified carbon paste electrode.

\section{Experimental}

\section{Reagent}

All chemicals were of analytical grade and have been used as received without any further purification. All solutions were prepared in double distilled water. The commercial graphite powder was supplied from France. The clay samples employed in the research were taken from the Natural Resources of Cameroon, more precisely from the town of Garoua, in the region of North Cameroon.

The bacterial strain used in this study was Staphylococcus aureus ATCC 25923. The strain was cultured in Luria Burtani broth at $37^{\circ} \mathrm{C}$ for $24 \mathrm{~h}$ after culture; the cells were harvested by centrifugation for 15 min at $8400 \times \mathrm{g}$ and were washed twice with and resuspended in $\mathrm{KNO}_{3}$ solution with ionic strength $0.1 \mathrm{M}$. The physicochemical properties of this strain were measured by contact angle measurements.

Provisions were made for oxygen removal by bubbling the solution with azotes gas for about 5 min then the solution was blanketed with azotes gas while the experiment was in progress. For reproducible results, a fresh solution was made for each experiment.

\section{Instrumental}

Voltammetric experiments were performed using a voltalab potentiostat (modelPGSTAT100, EcoChemie B.V., Utrecht, The Netherlands) driven by the general purpose electrochemical systems data processing software (voltalab master 4 software) run under windows 2007 . The three electrode system consisted of a chemically modified carbon paste electrode as the working electrode a saturated calomel electrode (SCE) serving as reference electrode, and platinum as an auxiliary electrode.

\section{Electrodes}

The working carbon paste electrode was prepared by mixing

*Corresponding author: Chtaini A, Faculty of Science and Technology, University Sultan Moulay Slimane, Bd Ibn Khaldoun, Beni-Mellal 23000, Morocco, Tel: +212661-118521; E-mail: a.chtaini@usms.ma

Received January 02, 2016; Accepted January 20, 2016; Published January 30 2016

Citation: Amlil A, Koffi OEAB, Bile BEA, Bengourram J, Najih R, et al. (2016) Electrochemical Biosensor for the Immediate Detection of Bacteria. J Biosens Bioelectron 7: 197. doi:10.4172/2155-6210.1000197

Copyright: ( 2016 Amlil A, et al. This is an open-access article distributed under the terms of the Creative Commons Attribution License, which permits unrestricted use, distribution, and reproduction in any medium, provided the original author and source are credited. 
appropriate weight of graphite powder with paraffin oil. The whole cell modified carbon paste was subsequently packed firmly into the electrode cavity $\left(0.1256 \mathrm{~cm}^{2}\right)$ and polished to a smooth shiny finish by gently rubbing over an ordinary weighing paper. Electrical contact was established with a bar of carbon. Amoxil-modified carbon paste electrodes (AMX-CPEs) were prepared by immobilizing the Amoxil system by soaking the preformed carbon paste electrode in a solution containing the Amoxil solution. The effect of the contact time (CT) of the CPE electrode with the Amoxil solution (1.5 M) was studied.

\section{Analytical procedure}

The modified carbon paste electrode was immersed in a cell containing bacteria sample to get a chemical accumulation. Meanwhile, the solution was rotated about $600 \mathrm{rpm}$ at open circuit. After a desired contact time, the electrode was removed from the preconcentration cell, rinsed with DW and placed in the measurement cell containing the supporting electrolyte $\left(1.0 \mathrm{~mol} \mathrm{~L} \mathrm{~L}^{-1} \mathrm{NaCl}\right)$. The solution was deaerated with nitrogen for $10 \mathrm{~min}$. The voltammetric curve was recorded. The same procedure was carried out in sample analysis and all electrochemical experiments were carried out at room temperature. The square wave voltammograms were recorded in different bacteria concentrations using $5 \mathrm{mV}$ of the pulse amplitude, step potential 50 $\mathrm{mV}$ and the duration time is $2 \mathrm{~s}$ at scan rate $1 \mathrm{mVs}^{-1}$.

\section{Results and Discussion}

\section{Cyclic Voltammetric (CV) experiments}

Preliminary CV experiments were performed to study the behavior at carbon paste electrode (CPE) and AMX-CPE. The electrodes were first immersed in an electrochemical cell containing $0.1 \mathrm{M} \mathrm{NaCl}$. Comparing CPE and AMX-CPE voltammograms (Figure 1), we find that the shape has changed which corresponds to a change of the surface morphology. The contact time of CPE with the antibiotic solution, has much influence on the shape of the cyclic voltammogram. For 10 minutes of contact, the current densities decrease considerably, which correspond, probably, to the formation start of the Amoxil film at the CPE surface. After 20 min of contact, the current densities decrease more, confirming the formation of a no conducting film on the electrode surface. Beyond 30 minutes of contact, the current densities increase, suggesting that the film begins to detach from surface. The contact time (CT) adopted is 20 min (Figure 1).

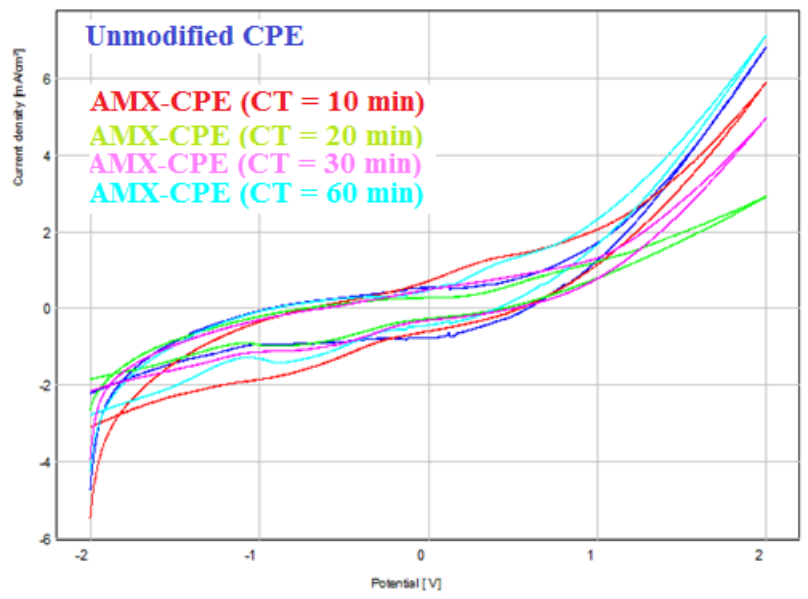

Figure 1: Cyclic voltammograms recorded in $0.1 \mathrm{M} \mathrm{NaCl}$ solution, at $\mathrm{CPE}$ and AMX-CPE, scan rate $100 \mathrm{mV} / \mathrm{s}$, at different CT.

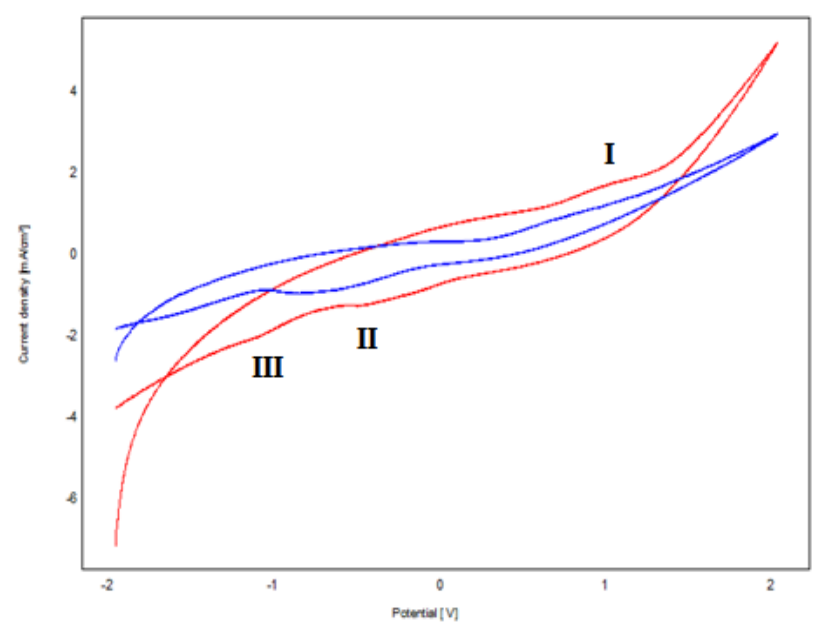

Figure 2: Cyclic voltammograms obtained by AMX-CPE, at $100 \mathrm{mV} / \mathrm{s}$, in $0.1 \mathrm{M} \mathrm{NaCl}$ solution, a- without bacteria, b- in presence of bacteria.

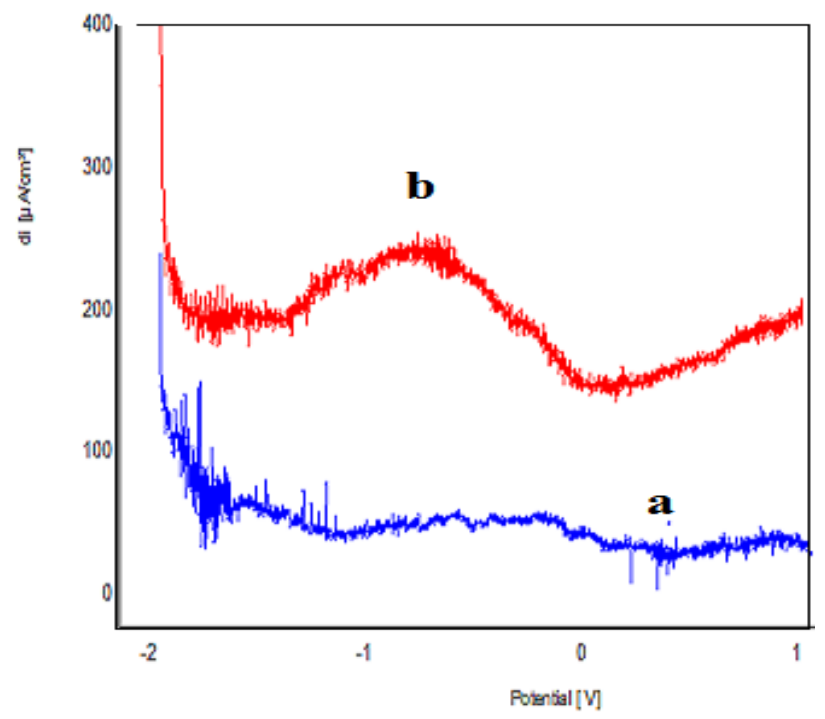

Figure 3: $S Q W$ voltammograms recorded at $A M X-C P E$, in $0.1 \mathrm{M} \mathrm{NaCl}$, awithout bacteria, $b$ - in presence of bacteria.

Figure 2 shows a cyclic voltammograms (CV) in the potential range $-0.2 \mathrm{~V}$ to $0.2 \mathrm{~V}$ recorded at Amoxil modified carbon paste electrode at $100 \mathrm{mV} . \mathrm{s}^{-1}$, when the AMX-CPE was dipped into the accumulation medium containing bacteria. The presence of bacteria in the AMX-CPE surface causes increased current densities CV and we can distinguish 3 peaks, an anodic peak at $0.94 \mathrm{~V}$, and two cathodic peaks, at $-0,44 \mathrm{~V}$ and $-1,14 \mathrm{~V}$. The ability of the AMX-CPE to accumulate bacteria was studied also by SWV. Figure 3 shows the square wave voltammograms (SWVs) obtained in $1.0 \mathrm{~mol} \mathrm{L^{-1 }} \mathrm{NaCl}$ before and after bacteria preconcentration on electrode surface, the SWV present a well-defined peak at $-1.2 \mathrm{~V}$. This peak was due to the reduction of bacteria system at AMX-CPE surface (Figure 3).

The dependence of peak current on the bacteria contact solution time was also investigated (Figure 4). The peak current increases with the increasing in the preconcentration time between 0 and $60 \mathrm{~min}$ above which it became nearly constant due to the surface saturation (Table 1). 
Citation: Amlil A, Koffi OEAB, Bile BEA, Bengourram J, Najih R, et al. (2016) Electrochemical Biosensor for the Immediate Detection of Bacteria. J Biosens Bioelectron 7: 197. doi:10.4172/2155-6210.1000197

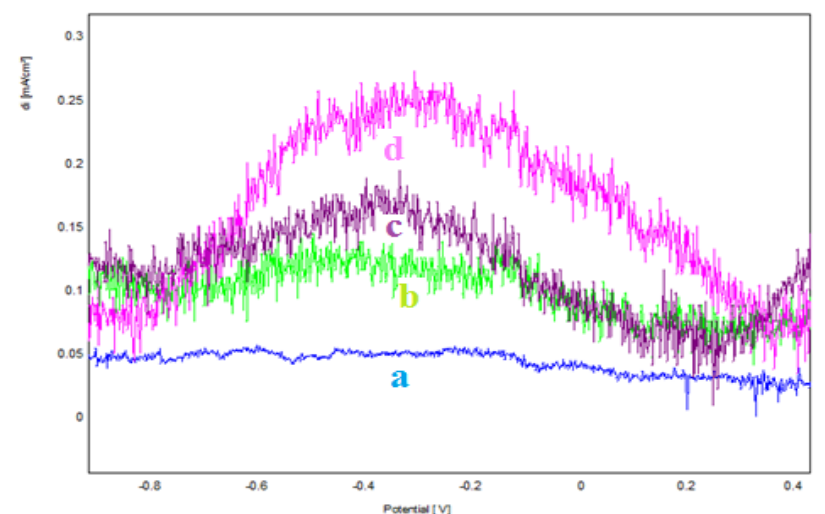

Figure 4: Square wave voltammograms recorded at $\mathrm{AMX}-\mathrm{CPE}$, in $1.0 \mathrm{~mol}$ $\mathrm{L}^{-1} \mathrm{NaCl}$, contact time effect.

\begin{tabular}{|l|c|c|c|c|c|c|c|}
\hline $\begin{array}{l}\text { Bacteria contact } \\
\text { time }(\mathbf{m i n})\end{array}$ & $\mathbf{0}$ & $\mathbf{4 0}$ & $\mathbf{6 0}$ & $\mathbf{8 0}$ & $\mathbf{1 0 0}$ & $\mathbf{1 2 0}$ & $\mathbf{1 4 0}$ \\
\hline $\mathrm{di}\left(\boldsymbol{\mu} \mathrm{A} / \mathbf{c m}^{2}\right)$ & 50 & 140.5 & 249,1 & 236,8 & 244,7 & 247,2 & 171,4 \\
\hline
\end{tabular}

Table 1: Influences of accumulation time of bacteria on AMX-CPE surface.

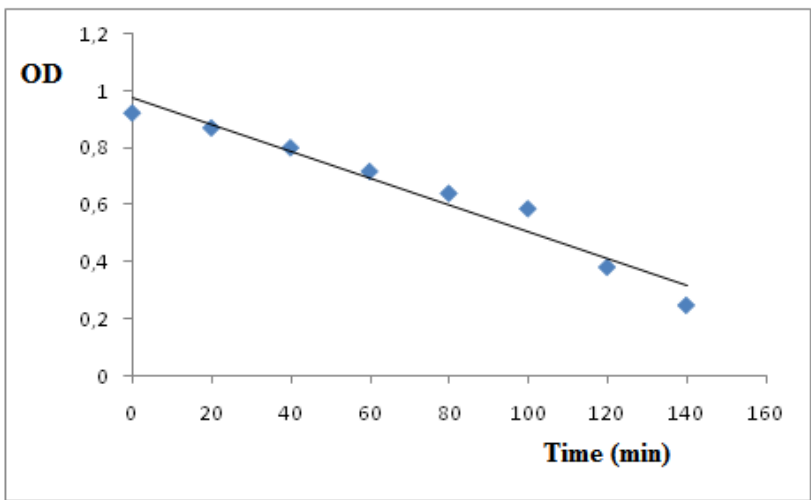

Figure 5: OD dependence of the contact time.

The evolution of the optical density (OD) of the bacteria preconcentrate solution with the contact time was studied. The OD value decreases with the contact time, which leaving argued that the AMX-CPE electrode promotes the extraction of bacteriafrom the solution. The OD measured by a photometer depends strongly on the contact time. Figure 5 showed a typical linear response, which can be expressed according to the following equation:

$$
\mathrm{OD}=-0,004 \mathrm{CT}+0,977
$$

As far as the electrode conditions are concerned, the amount of antibiotic is a control factor of great importance. As expected, an increase in amount of Amoxil gives a higher peak current and the peak potential remains constant (Figure 6). When the amount of Amoxil exceeds $0.13 \mathrm{~mol} / \mathrm{L}$, the peak current density decreases. Presumably, more antibiotic at the electrode surface reduces the amount of conductive area of the activated graphite particle.

The Figure 6 shows the optical microscopic images, recorded respectively, for CPE (a), AMX-CPE (b) and AMX-CPE after $20 \mathrm{~min}$ of contact with bacteria solution (c) electrodes. We note that the antibiotic film forms a thin layer that covers the all carbon surface.

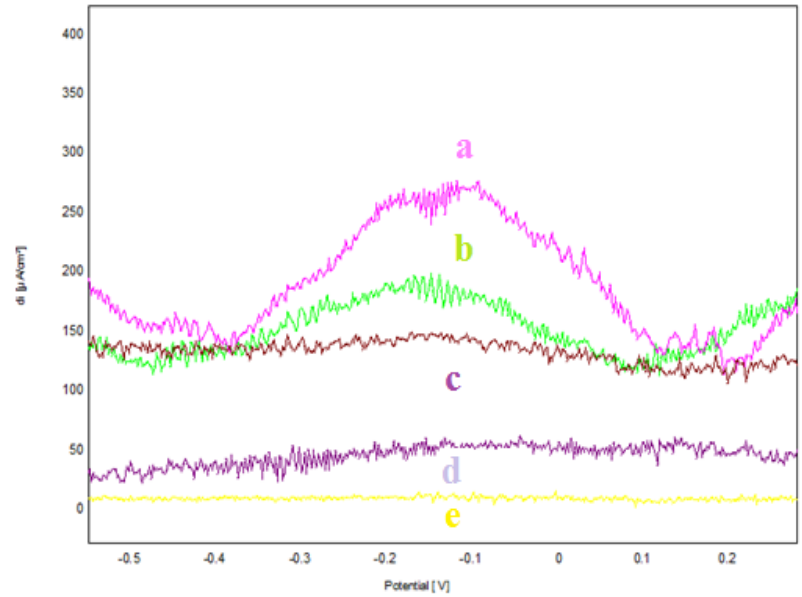

Figure 6: Influence of amount modifier on peaks current, a- $0.13 \mathrm{M}$ (antibiotic), b- $0.065 \mathrm{M}, \mathrm{c}-0.26 \mathrm{M}, \mathrm{d}-0.52 \mathrm{M}$.
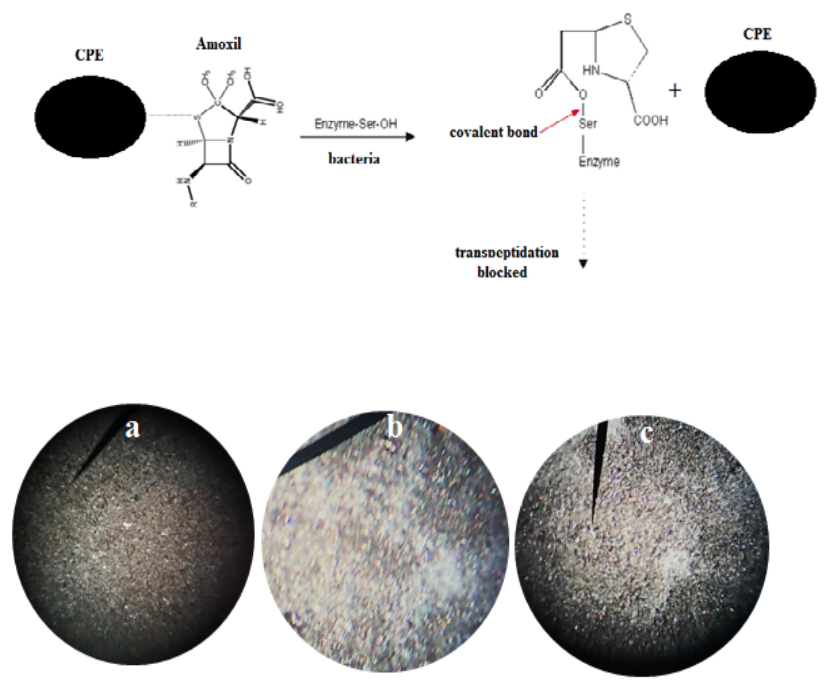

Figure 7: Optical microscopic image corresponding to a- CPE, b- AMX-CPE and c- AMX-CPE after bacteria accumulation.

After impregnation in the pre-concentration solution containing the bacteria, we find that the AMX-CPE electrode surface shows large aggregations of bacteria concentrated on part of the surface, in the rest of the surface, we can distinguish the isolated carbon graphite, This suggests that the bacteria are adsorbed at first time on the amoxil, forming strong bonds, which cause embrittlement subsequently of an Antibiotic-carbon bonds, resulting in the detachment of bacteria -antibiotic-substrate by following mechanism (Figure 7).

\section{Conclusion}

A novel Amoxil modified carbon paste electrode was prepared. The modified electrode is highly sensitive towards unmodified carbon paste electrode and provides a rapid response. In the present work, the influence of contact time towards peak current response has been investigated by SWV, and effect of amount of antibiotic was highlighted to analyze the prepared electrode ability to absorb bacteria. The proposed biosensor exhibited good reproductiblity, stability and 
Citation: Amlil A, Koffi OEAB, Bile BEA, Bengourram J, Najih R, et al. (2016) Electrochemical Biosensor for the Immediate Detection of Bacteria. J Biosens Bioelectron 7: 197. doi:10.4172/2155-6210.1000197

efficiency. AMX-CPE can be able to selectivity detect a living organism such as Staphylococcus aureus.

In perspective, this work will be chained by the study of interference caused by the presence simultaneously, of multiple bacteria, and we plan to do an analytical application in conditions close to reality.

\section{References}

1. Ahmed MU, Nahar S, Safavieh M, Zoroub M (2013) Real-time electrochemical detection of pathogen DNA using electrostatic interaction of a redox probe. Analyst 138: 907-915.

2. Chen L, West J, Auroux AP, Manz A, Day PJR (2007) Ultrasensitive PCR and real-time detection from human genomic samples using a bidirectional flow microreactor. Analytical chemistry 79: 9185-9190.

3. Compton J (1991) Nucleic acid sequence-based amplification. Nature 350: 91-92.
4. Craw P, Balachandran W (2012) Isothermal nucleic acid amplification technologies for point-of-care diagnostics: a critical review. Lab Chip 12: 2469-2486.

5. Drummond TG, Hill MG, Barton JK (2003) Electrochemical DNA sensors. Nat Biotechnol 21: 1192-1199.

6. Defevre T, Druet M, Evrard D, Marchal D, Limoges B (2011) Real-Time Electrochemical PCR with a DNA Intercalating Redox Probe. Anal Chem 83: 1815-1821.

7. Pozo MVD, Alonso C, Pariente F, Lorenzo E (2005) Electrochemical DNA sensing using osmium complexes as hybridization indicators. Biosens Bioelectron 20: 1549-1558.

8. Mahalanabis M, Do J, Hussam ALM, Zhang JY, Klapperich CM (2010) An integrated disposable device for DNA extraction and helicase dependent amplification. Biomed Microdevices 12: 353-359. 